\title{
THE NEED FOR THE ENFORCEMENT OF ENVIRONMENTAL STANDARDS IN THE IRANIAN OIL AND GAS INDUSTRY: NARROWING THE ACCOUNTABILITY GAP
}

Naimeh Masumy*

\begin{abstract}
Although the oil and gas industry has boosted Iran's economic development, it has adversely affected the ecosystems of certain regions. The government has failed to establish appropriate environmental regulations to prevent industry from engaging in environmentally damaging projects. Indigenous people living in naturally oil- and gas-rich areas already experience conditions of severe social disadvantage, ${ }^{1}$ and are additionally subject to suffering the consequences of an unregulated oil and gas industry. Major shortcomings in national environmental law and the lack of effective compliance mechanisms have left indigenous people without recourse to legal action. This paper critiques the existing legal frameworks and identifies the deficiencies in their accountability mechanisms, that is, the methods by which affected groups may hold companies responsible for environmental harms in the context of oil and gas exploration projects. It also scrutinises the non-compulsory nature of current international standards. This paper contends that, at present, companies are not obligated to adhere to these standards, which renders them ineffective. It argues for an alternative legal framework that can facilitate accountability in the Iranian environmental regulation system.
\end{abstract}

\section{A. INTRODUCTION}

The petroleum industry in Khuzestan poses significant threats to local indigenous populations. It has caused damage to the environment through infrastructure that has diminished iconic wetlands, such as those in Maku and Akes, by excessively pumping water, which overdraws the ground water. ${ }^{2}$ The Ahwazi ${ }^{3}$ people largely depend on these lands for farming and fishing, ${ }^{4}$ however they have been increasingly dispossessed of their land due to the proliferation of oil and gas operations. ${ }^{5}$ In 2012, Dr Roddolfo Stavenhagen, former Special Rapporteur on the rights of indigenous peoples, reported that indigenous people have been 'subjected to extreme

\footnotetext{
* LLM 2011 (University of Pennsylvania); LLM 2016 (UCL). I am especially grateful to Professor Jelena Madir and Kyra Nezami for her guidance and instruction throughout the writing process. I would also like to express my gratitude to Zephyr Hicks and the academic editors at UCLJLJ for their valuable comments and diligent work on this article. All remaining errors are mine alone.

${ }^{1}$ For the purpose of this paper, the term 'indigenous people' refers to an Arab minority living in the Khuzestan province.

2 'How Iran's Khuzestan went from wetland to wasteland' The Guardian (London, 16 April 2015)

$<$ https://www.theguardian.com/world/iran-blog/2015/apr/16/iran-khuzestan-environment-wetlands-dustpollution> accessed 21 April 2017.

3 UNPO, 'Ahwazi' (Unrepresented Nations and Peoples Organization, 25 March 2008) $<$ unpo.org/members/7857> accessed 12 May 2017.

${ }^{4}$ Corrine Lennox, 'Natural Resource Development and Rights of Minorities and Indigenous Peoples' (Minority Rights, 2012) $12<$ https://www.researchgate.net/profile/Corinne_Lennox> accessed 20 January 2018.

5 Barry Turner, 'Unrepresented Nations and Peoples Organization (UNPO)' in Barry Turner (ed), The Statesman's Yearbook (Palgrave Macmillan 2005) 89.
} 
poverty and persistent discrimination'. ${ }^{6}$ The Ahwazi have no voice in terms of managing lands that are culturally and historically significant to them; indigenous people in Iran rarely enjoy legal title to the lands they occupy, let alone the underlying mineral resources, which the national government retains the right to extract. ${ }^{7}$ Further, in recent years, Khuzestan has experienced significant increases in life-threatening diseases linked to air and water pollution; it is now one of the world's most air-polluted cities. ${ }^{8}$

The current regulatory regime in Iran has left indigenous populations vulnerable to exploitation, ${ }^{9}$ and has been labelled as 'outdated'. ${ }^{10}$ The right of local communities to access justice, as this paper will argue, is not properly enshrined in the current regulatory regime. ${ }^{11}$ Moreover, the need for critical analysis of the current regulatory landscape in Iran seems all the more pressing as local populations appear to be subject to the after effects of the oil and gas industry's unrestrained growth in terms of individual health. Other issues of concern include damage to local economies, the destruction of ecosystems and the demolition of cultural sites. ${ }^{12}$ Another potential problem lies in security challenges for Iran. Notably, there is social unrest in the regions affected by environmental degradation. ${ }^{13}$ Arab-speaking minorities, without recourse to protect their land from destruction, may seek help from neighbouring countries such Saudi Arabia or Bahrain. This could deepen tensions between Iran and its Arabic neighbours. ${ }^{14}$

Shortcomings in the national regulatory scheme and the absence of mechanisms to hold oil and gas companies to account are particular problems in these regions. ${ }^{15}$ An improved legal framework is therefore needed to ensure that local communities and indigenous people do not

\footnotetext{
6 'Special Rapporteur on Human Rights of Indigenous People' (United Nations, 8 April 2004) $<$ www.un.org/press/en/2004/hrcn1079.doc.htm > accessed 10 June 2017.

${ }^{7}$ Joachim von Braun, Ruth Vargas Hill and Rajul Pandya-Lorch (eds) 'The Poorest and Hungry: Assessment, Analyses, and Actions', (International Food Policy Research Institute 2009) 29.

${ }^{8}$ Seyed Shadizadeh and Mansoor Zoveidavianpoor, 'The Role of Clay as a Natural Geological Barrier in Oil Pollution Control of Abadan Refinery’ (2010) 19 Geosciences 177.

${ }^{9}$ Morad Tahbaz, 'Environmental Challenges in Today’s Iran' (2016) 49(6) Iranian Studies 943, 950-954.

10 'Legal Vacuum Harming Environment' Financial Tribune (Tehran, 28 February 2017) $<$ https://financialtribune.com/articles/people-environment/60489/legal-vacuum-harming-environment> accessed 11 August 2017.

${ }^{11}$ Nazlia Ghanea and Binesh Hass, 'Seeking Justice and an End to Neglect: Iran's minorities today' (Minorities Rights, 10 January 2010) 8. <http://www.refworld.org/pdfid/4d8ae8852.pdf> accessed 10 January 2018.

12 Rahim Hamid, 'Ahwazi Arabs: The Forgotten Struggle for Stolen Rights and Cultural Identity' Al Mezmaah (Dubai, 21 February 2016) <almezmaah.com/english/2016/02/21/ahwazi-arabs-the-forgotten-struggle-forstolen-rights-and-cultural-identity> accessed 10 August 2017.

13 ibid.

14 Isabel Coles, 'Iran's Arab Minority Drawn into Middle East Unrest' Reuters (15 August 2013) $<$ https://www.reuters.com/article/us-iran-arabs-insight/insight-irans-arab-minority-drawn-into-middle-eastunrest-idUSBRE97E0O620130815> accessed 3 August 2017.

15 Mehdi Piri and Michael Faure, 'The Effectiveness of Cross-Border Pipeline Safety and Environmental Regulations' (2014) 40(1) North Carolina Journal of International Law and Commercial Regulation 55, 74.
} 
bear the heavy environmental and social costs in the context of oil and gas exploration and development projects. ${ }^{16}$

As such, the paper proposes developing a national regulatory scheme and devising mechanisms that can foster public participation in the planning process for oil and gas industry construction projects. This proposed framework would provide affected communities greater access to information, allowing them to take part in the project design, approval and preconstruction phases. It would also offer local communities a platform to voice their concerns and, in turn, enhance the socio-environmental rights of indigenous people and their affected communities.

This article is divided into two substantive sections. The first section illustrates the shortcomings of the current environmental regulations (or lack thereof) in Iran, arguing that they represent insufficient means by which to ensure protection for indigenous people. This section critically examines the failure of these standards to offer adequate protection of indigenous communities' rights. The second section suggests a new national legal framework that could uphold the rights of indigenous people and contends that the oil and gas industry in Iran must become more sustainable.

\section{B. ENVIRONMENTAL IMPACT ASSESSMENTS AND INTERNATIONAL STANDARDS - DEFICIENCIES IN THE CURRENT IRANIAN REGULATORY SCHEME}

The current Iranian environmental legal regime for oil and gas projects is the Environmental Impact Assessment (EIA). The EIA is the only Iranian regulatory scheme that ensures that the environmental implications of proposed projects are taken into account before decisions about oil and gas projects are made. ${ }^{17}$ This article contends that the EIA has failed to adequately assess the socio-environmental risks involved with expanding the petroleum-related industry in Iran, and does not meet international accountability standards. This section will also examine international environmental standards (international standards) and how they apply in the current Iranian legal regime. However, the central criticism this section addresses is that both the EIA regime and the international standards fail to adequately account for local communities' participatory rights in oil and gas projects.

\footnotetext{
${ }^{16}$ Edward McCutheon, 'Think Globally, Enact Locally: Promoting Effective National Environmental Regulatory Infrastructures in Developing Nations' (1998) 31 Cornell International Law Journal 395, 398.

${ }^{17}$ Hossein Yousefi, Younes Noorollahi and Setare Peirow 'Iran-Status of Environmental Impact Assessment' (2015) 45(6) Environmental Policy and Law 320, 322.
} 


\section{The EIA Framework}

The EIA framework was formally established through a 2012 decree, subsequently amended in 2016, called General Conditions, Structure and Template of Upstream Oil and Gas Contracts (the Decree). ${ }^{18}$ Under the Decree, the EIA is defined as a study designed to predict and identify the potential environmental effects of a project ${ }^{19}$ and the Decree also suggests the inclusion of the EIA report into the environmental management plan as a mandatory step in obtaining a permit. In 2014 the Supreme Environment Protection Council confirmed this approach. ${ }^{20}$

From a procedural perspective, Article 2 of the Decree requires one of the parties to a transaction to conduct an EIA while site selection and feasibility studies are in progress. ${ }^{21}$ That party must then send the report to the Department of the Environment to obtain an official permit prior to taking any operative action. According to Article 8 of the Decree, the first party to the contract, who is the grantor of the right to explore and produce, usually gives instruction to the second party to conduct an environmental management plan. However, Article 11 of the Decree provides for the National Iranian Oil Companies' (NIOC) subsidiaries to participate during the operation and production phase. If the NIOC considers such a partnership necessary, the second party and the NIOC subsidiary enter into a joint operation agreement.

Nevertheless, despite the NIOC's participation, the responsibility for conducting the EIA falls on the second party. ${ }^{22}$ This indicates the Iranian government's reluctance to conduct EIAs, despite having the necessary expertise and resources to do so. It is important to note that both the Supreme Environment Protection Council and NIOC are executive branch entities. This means, in effect, the current Iranian regulatory regime allows government agencies a wide discretion in approving oil and gas exploration and development activities. ${ }^{23}$

The EIA mechanism has also been criticised for failing to protect indigenous people from harm for the reasons outlined below. ${ }^{24}$ For example, whilst the Decree requires 'compliance with safety, health, environmental and social considerations in the implementation of a project', ${ }^{25}$ it does not define the term 'considerations'. This lack of specificity means that

\footnotetext{
${ }^{18}$ Cabinet decree No H45880T/214287 (23 January 2012), amended by decree No H52087T/43465 (5 July 2016) Preamble (Decree Law).

${ }^{19}$ Mona Kashfi, 'Cabinet Approves General Conditions Governing Iran's Upstream Oil and Gas Contract' (2017) 10(2) Journal of World Energy Law and Business 136, 138.

${ }^{20}$ Decision No 144479/45880 of the Supreme Environment Protection Council (12 October 2011).

${ }^{21}$ Decree Law, art 2.

${ }^{22}$ Kashfi (n 19) 140.

${ }^{23}$ Nima Shahri, 'The Petroleum Legal Framework of Iran: History, Trends and the Way Forward' (2010) 8 China and Eurasia Forum Quarterly 111.

${ }^{24}$ Kashfi (n 19) 146.

${ }^{25}$ Decree Law, Preamble.
} 
environmental risks are not adequately addressed, which has particular significance in the context of indigenous communities. It also means the responsibility owed by project developers and lenders to indigenous people is not laid out clearly in the regulatory framework.

Recent attempts to address this lack of clarity have not led to further protection of the rights of indigenous people. In 2014, the Supreme Environmental Protection Council held, when interpreting ambiguities within the Decree, that parties could rely on industry best standards or international standards, such as the IFC policies and the EPs. ${ }^{26}$ The decision of the Supreme Environmental Protection Council gave substantial discretion to the parties to rely on some of the environmental protection standards stipulated in the EPs and IFC frameworks. However, the parties are not required to adopt these standards and they are given a wide discretion to choose which, if any, provision they adopt. In addition, amendments to the Decree have allowed contract drafters to rely on international regulations or industry best practices when drawing up and implementing environmental impact management plans. ${ }^{27}$ Consequently, the international regulations do not offer comprehensive protection to indigenous people, whilst the lack of detailed provisions regarding environmental considerations has also rendered them ineffective. In sum, these changes and the decision by the Supreme Environmental Protection Council gives substantial discretion to the parties to determine what international (environmental) considerations, if any, will appear in contracts. ${ }^{28}$

Further, the EIA does not account for risks that arise once the proposed project is in operation. As Wildavsky notes, social and environmental phenomena change frequently and should thus be monitored regularly; risks can be highly varied and unpredictable, depending on the infrastructure's location. ${ }^{29}$ A static model such as the EIA, which focuses on identifying risks at the outset of an operation, cannot adequately account for the shifting nature of those risks.

A pertinent illustration of the existing model's inadequacy when it comes to risk is evident in the experiences of indigenous people in Lorestan, where a large gas infrastructure was planned for construction by China National Petroleum Corporation (CNPC) in the Baba Habib oil and gas field. ${ }^{30}$ In this case, an EIA was conducted, the project commenced and,

\footnotetext{
${ }^{26}$ Kahshfi (n 19) 146.

27 ibid 144, 145.

28 ibid 144.

${ }^{29}$ Aaron Wildavsky, Risk and Culture (University of California Press 1982).

30 Editorial, 'Shale Gas Discovery In Western Iran' Financial Tribune (Tehran, 4 January 2017) $<$ https://financialtribune.com/articles/energy/56880/shale-gas-discovery-in-western-iran $>$ accessed 16 January 2017.
} 
during the final phase of construction, the gas pipeline erupted. The leaking oil caused massive destruction in areas of historical significance for local communities, namely the Romeshakan Mountain and Darmareh province. The risk management model the EIA employed in this project to quantify and calculate risk possessed a structural limitation in terms of capturing the full extent of the socio-environmental risks facing the affected communities. ${ }^{31}$ The limitation is inherent in static nature of EIAs, which are unable to capture unforeseeable risks. As Amalric argues, many social and environmental issues cannot be financially quantified using techniques familiar to financial institutions or EIA. ${ }^{32}$

Consequently, the current regulatory regime in Iran cannot address risks that may arise throughout a project's duration nor can it capture social and environmental realities. EIAs require projects to be analysed in terms of their potential adverse impacts on the environment. ${ }^{33}$ Therefore, whilst the EIA engages with the concept of environmental damage, this author would argue that it does not adequately address potential socio-environmental harms, that is, damage done to local communities, damage done to individual livelihoods, loss of profit for local businesses, and the erasure of subsistence rights, especially for local communities engaged in the fishing economy. Moreover, the EIA process does not capture the after-effects of environmental damage.

\section{International Environmental Standards: the Environmental Safeguard Policies and the Equator Principles}

The EIA framework in Iran is supplemented by the use of international standards. The international standards applied today in the context of oil and gas infrastructure and exploration refer to both the Environmental Safeguard Policies (ESP) and the Equator Principles (EP), which came to existence in $2008 .{ }^{34}$ These current international standards are voluntary and non-binding, which proves problematic.

\footnotetext{
${ }^{31}$ Javad Nouri and H Nikoomaram, 'Comparison of the Environmental Impact Assessment Procedure in with Other Countries' (2005) 1 European Journal of Scientific Research 87, 90.

${ }^{32}$ Franck Amalric, 'The Equator Principles: A Step toward Sustainability' (2005) CCRS Working Paper Series, No 01/05 <https://www.nachhaltigkeit.info/media/1317385761phpOHcawW.pdf $>$ accessed 2 July 2017.

${ }^{33}$ Howard Brown, 'Expanding the Effectiveness of the European Union's Environmental Impact Assessment Law’ (1997) 20 Boston College International \& Comparative Law Review 313, 315.

34 Elisa Morgera, 'Significant Trends in Corporate Environmental Accountability: The New Performance Standards of the International Finance Corporation' (2007) 18 Colorado Journal of International Environmental Law \& Policy 147, 152. For further information regarding Safeguard policies and the Equator Principles please see $\quad<$ http://equator-principles.com./wp-content/uploads/2017/03/equator_principles_III.pdf $>\quad$ and $<$ http://www.worldbank.org/en/programs/environmental-and-social-policies-for-projects/brief/environmentaland-social-safeguards-policies $>$.
} 
The ESPs were established by the International Finance Corporation (IFC), ${ }^{35}$ in response to public backlash faced by the World Bank during the 1960s when funding was awarded to controversial projects, such as the Narmada Dam project in Western India and Polonrest Highway in Brazil. ${ }^{36}$ Both of these projects were funded with limited consideration for the environment and local communities. ${ }^{37}$ In the wake of these controversies, private institutions began adopting environmental and social standards to demonstrate their ethical and environmental awareness. ${ }^{38}$ Specifically, both the ESPs and the EPs were developed to ensure financing activities taken by banks are conducted in an environmentally sound manner. Thus, the introduction of ESPs forced banks to broaden their scope of due diligence and improve their socio-environmental standards. ${ }^{39}$ They also led to a requirement that corporations engage with communities affected by developments and provide them with access to information pertinent to the project. ${ }^{40}$ Moreover, the principles within the ESP state that, where a corporation has undertaken a social and environmental assessment regarding a proposed development, it is required to publicly disclose that assessment. ${ }^{41}$ The ESP also requires corporations and banks to establish grievance mechanisms if there are ongoing risks or adverse effects anticipated to an affected community. ${ }^{42}$

The EPs emerged as another set of voluntary standards in 2006, largely replacing the ESP. ${ }^{43}$ The EPs urge banks to adhere to social and environmental standards during their financing activities. ${ }^{44}$ Launched in 2003 by several large international banks, EPs 'seek to ensure that the projects [they] finance are developed in a manner that is socially responsible and reflects sound environmental management practices'. ${ }^{45}$ Financial institutions are strongly advised to embed these principles into their loan agreements and to refuse to provide loans to projects where the borrower is unable to comply with these policies. ${ }^{46}$

35 IFC, 'IFC's Policy and Performance Standards on Social and Environmental Sustainability' (World Bank Group 2012).

${ }^{36}$ Alf Morten Jerve, 'Social Consequence of Development in a Human Rights Perspective: Lessons from the World Bank' (1998) 45 Human Rights in Development Yearbook 35, 38.

37 IFC (n 35).

38 Andrew Hardenbrook, 'The Equator Principles: The Private Financial Sector's Attempt at Environmental Responsibility’ (2007) 40(197) Vanderbilt Journal of Transnational Law 197, 205.

39 ibid 209, 225.

${ }^{40}$ IFC (n 35).

41 ibid.

42 ibid.

${ }^{43}$ David Hunter, 'Civil Society Networks and the Development of Environmental Standards at International Financial Institutions' (2008) 8 Chicago Journal of International Law 437.

${ }^{44}$ Hardenbrook (n 38) 224, 226.

45 Equator Principles, 'Equator Principles' (Equator Principles, June 2013) <www.equatorprinciples.com/resources/equator_principles_III.pdf> accessed 9 June 2017.

${ }^{46}$ Hardenbrook (n 38) 204. 
As such, it appears as though EPs offer a step in the right direction, in that they attempt to enshrine the public right to participate in projects that affect the environment and the community. For example, under the EPs framework, certain projects like the Arun Dam in Nepal and the Western Poverty Reduction in China have been denied financing due to environmental and social concerns. ${ }^{47}$ Despite this improvement, however, it is asserted that the inability to enforce international standards renders them ineffective in achieving their objective. $^{48}$

\section{a) Enforcement of International Standards}

The voluntary nature of the international standards has been questioned by some commentators. ${ }^{49}$ Specifically, it has been queried whether self-regulatory activities represent an exercise in 'greenwashing' rather than an honest attempt to establish environmentally responsible standards of conduct. ${ }^{50}$ At present, the voluntary adoption of international standards by corporations means they are perceived more as a commitment to developing internal policies and practices than an effective tool. This self-regulatory system lacks an enforcement method, such as persuasive measures, warnings, civil penalties, sanctions or license suspensions. ${ }^{51}$ As Barrett and Mach contend, EPs cannot serve any real purpose without their enforcement being monitored; ${ }^{52}$ a punitive deterrent must be enacted when parties fail to act in accordance with the standards. Comparably, it has been asserted that the EPs do not encourage financiers to appoint independent panels to assess and monitor their implementation, thereby confirming an Equator Principles Financial Institutions (EPFI) reluctance to enact a responsive regulatory system to oversee these actions. ${ }^{53}$ In fact, monitoring has been described as the 'true Achilles heel of the equator principles'. ${ }^{54}$ Further, there is no monitoring body to

\footnotetext{
${ }^{47}$ Benjamin Sovacool, 'Cooperative or Inoperative? Accountability and Transparency at the World Bank's Inspection Panel' (2017) Case Studies in the Environment 1, 4. $<$ http://cse.ucpress.edu/content/ecs/early/2017/10/12/cse.2017.000463.full.pdf > accessed 8 June 2017.

${ }^{48}$ McCutheon (n 16) 438, 440.

49 Ian Ayres and John Braithwaite, Responsive Regulation: Transcending the Deregulation Debate (Oxford University Press 1992) 7, 25, 51.

${ }^{50}$ Robert Baldwin and Julia Black, 'Really Responsive Regulation’ (2008) 71 Modern Law Review 59, 62.

${ }^{51}$ Lindsay Hall, 'Reconciling Enforcement Weaknesses and Lender Liabilities in The Equator Principles' (2014) 5(1) George Washington Journal of Energy \& Environmental Law 72.

52 James Barrett and Joel Mack, 'Paying for Their Principles' (Latham and Watkins LLP, February 2004) $<$ https://www.lw.com/upload/pubContent/_pdf/pub939_1.pdf > accessed 19 August 2017.

53 Freshfields Bruckhaus Deringer, 'Banking on Responsibility' (Freshfields Bruckhaus Deringer, 2005) $<$ https://www.banktrack.org/download/banking_on_responsibility/050701_banking_on_responsibility.pdf > accessed 2 July 2017.

54 ibid 10-19.
} 
respond when an EPFI breaches the principles. Lee and Egede are similarly critical, observing that the EP's 'impact may be slight owing to poor monitoring and enforcement in practice'. ${ }^{55}$

In practice, despite the existence of EPs, corporations do not efficiently mitigate against causing environmental harm. It has been noted that these new set of performance standards are outcomes-based and this allows investors significant discretion when interpreting what constitutes environmental or social due diligence. These standards are also self-regulatory, meaning they 'are entered into in response to the existence or absence of first-order government regulatory requirements' ${ }^{56}$ This demonstrates that, as the agreements are made between private parties and government organisations, indigenous people cannot rely on international standards to create specific obligations towards them. It follows that these standards do not offer local communities any procedural or substantive rights in relation to infrastructure projects.

Nevertheless, international standards can be seen as providing a weak enforcement mechanism through loan documentation. EP III, the incorporation of which into loan documentation has become common practice, ${ }^{57}$ states that the borrower must agree to a borrower's compliance covenant in the loan agreement. ${ }^{58}$ This supports the view that the adoption of EPs represents a bank's commitment to implementing environmentally sound policies by incorporating such provisions into loan agreements. ${ }^{59}$ Furthermore, lenders are strongly advised to consider environmental concerns in the key components of a loan agreement, such as through representation and warranties, condition precedents and covenants. These have operative effect, by providing the lender with certain rights (discussed below) in the event of a violation or breach of any stipulated provisions. Lenders are also urged to put environmental concerns in the definition section of the loan agreement so that parties are aware in sufficiently specific terms of what the relevant environmental considerations are and what constitutes compliance. ${ }^{60}$

Whilst including appropriate covenants in loan agreements is welcomed, it does not ensure compliance with the international standards, as no effective sanction mechanism exists

\footnotetext{
${ }^{55}$ Robert Lee and Tamara Egede, 'Bank Lending and the Environment Liability: Not Liability but Responsibility' (2007) The Journal of Business Law 868, 875.

${ }^{56}$ Michael Vandenvergh, 'The Private Life of Public Law' (2005) 105 Columbia Law Review, 65, 66.

${ }^{57}$ Scott Hoffman, The Law and Business of International Project Finance ( $3^{\text {rd }} \mathrm{edn}$, Cambridge University Press 2008).

${ }^{58}$ Bede Nwete, 'The Equator Principles - How far Will it Affect Project Financing' (2005) International Business Law Journal 173, 180.

59 ibid $174,175$.

${ }^{60}$ Equator Principles Financial Institutions, 'Guidance for EPFIs on Incorporating Environmental and Social Considerations into Loan Documentation’ (Equator Principles, March 2014) <http://equator-principles.com/wpcontent/uploads/2017/03/ep_guidance_for_epfis_on_loan_documentation_march_2014.pdf $>$ accessed 5 January 2018.
} 
when a lender or borrower breaches the EPs. Where a loan agreement makes specific reference to environmental considerations, this gives the bank the power to suspend disbursement, for example, if the borrower or project developer defaults in performing its agreed actions. Further, where the borrower does not take acceptable action within a specified period, the bank can also accelerate the loan maturity and insist on immediate payment of the loan in full. However, it is argued that these enforcement mechanisms are not implemented in practice. A bank enforcing environmental considerations by threatening loan default is rare-if a bank announces default, collateral becomes due and payable, thus preventing the bank from reaping the benefits of return interest. ${ }^{61}$ This is problematic, considering financial institutions' general tendency to emphasise short-term interest over long-term interest. In this context, the long-term interest is the longevity of the banks' sound operation rather than an immediate boost or exponential growth in financial returns of any given investment. ${ }^{62}$ This tendency to favour short-term interests has become more prominent with the emergence of the recent financial crisis. As Sarro contends, experience 'seems to support this view of lender's interest. As of September 2012, no EPFI has declared a default event on the basis of a breach of the Equator Principles'. ${ }^{63}$ Rather, this type of contract is the most effective in situations in which the party seeking to uphold the covenant, normally the financial institution, can 'effectively monitor their borrower's conduct' ${ }^{64}$ Nonetheless, aside from the contractual provisions that may be included in the loan agreement, there is no effective mechanism in place to ensure compliance through annual reporting in relation to the relevant project and no mechanism for sanctions if the specified covenant is violated. ${ }^{65}$

A further issue with the self-regulating nature of international standards is that granting the banks the power to announce a default provides banks with substantial discretion but creates no mechanism to incentivise EPFIs to ensure that borrowers comply with their obligations under the loan agreement. ${ }^{66}$ If a bank refuses to declare a default, there is no plausible way for either national authorities or indigenous communities to hold project developers accountable for their non-compliance. Thus, the inability to sanction EPFIs, where they choose not to

\footnotetext{
${ }^{61}$ John Dewar (ed), International Project Finance: Law and Practice (2 ${ }^{\text {nd }}$ edn, Oxford University Press 2015) 180.

${ }^{62}$ Hardenbrook (n 38) 201.

${ }^{63}$ Douglas Sarro, 'Do Lenders Make Effective Regulators? An Assessment of the Equator Principles on Project Finance' (2012) 13 German Law Journal 1523, 1524.

${ }^{64}$ ibid 1524.

${ }^{65}$ Hoffman (n 57) 201.

${ }^{66}$ Tomer Broude, 'Behavioral International Law' (2014) 163 University of Pennsylvania Law Review 1099 , 1137.
} 
declare a default, demonstrates the inadequacy of the international standards. The international standards are only effective where a lender (EPFI) chooses to enforce them and thus ensure the borrower's compliance with the standards.

\section{Interaction of the EIA Framework and International Standards}

The Decree, along with statements from the Environmental Supreme Council, suggest that international standards may be used to regulate construction projects in Iran and ensure that they adhere to environmental requirements. ${ }^{67}$ However, reference to international standards and industry best practices does not adequately address the shortcomings of Iran's EIA model; together the EIA framework and international standards still fail to protect indigenous people's rights. A central problem of the current regulatory framework in Iran is its inattention to participatory rights and, further, the absence of a liability mechanism, or even a formal commitment on behalf of the NIOC, or project sponsors, to apply the provisions stipulated in the EIA. Although it is sometimes argued that international standards included in the EIA encourage companies to act more responsibly, the absence of requirements for systematic follow-up on implementation means that these standards do not have the necessary effect.

\section{The Iranian Regulatory Scheme and a Right to Public Participation}

The notion of public participation, as enshrined in international environmental law, was first articulated in the Rio Declaration on Environment and Development (Rio Declaration). ${ }^{68}$ The Rio Declaration requires State parties to collect and publicly disseminate information on policies relating to the environment. ${ }^{69}$ Furthermore, it has been noted that 'opportunities for people to influence their lives and future, participate in decision-making and voice their concerns are fundamental for sustainable development'. ${ }^{70}$ This right of public participation is therefore designed to empower, not exclusively but particularly, indigenous people in oil and gas projects and enhance their environmental protection ${ }^{71}$ by ensuring that private citizens are involved in environmental decision-making procedures. ${ }^{72}$ The right includes three main pillars:

67 US Energy Information Administration, 'Iran Country Analysis Brief' (US Energy Information Administration, 19 June 2015) <https://www.eia.gov/beta/international/analysis.cfm?iso=IRN $>$ accessed 11 August 2017.

${ }^{68}$ Volker Mauerhofer, 'Public participation in environmental matters: Compendium, challenges and chances globally’ (2016) 52 Land Use Policy 481, 481.

69 UNGA, 'Rio Declaration on Environment and Development' (12 August 1992) UN Doc A/CONF.151/26, Principle 10 (Rio Declaration).

${ }^{70}$ UNHCR, 'Resolution Adopted by the General Assembly on 27 July 2012: The Future We Want' (27 July 2012) UN Doc A/Res/66/288 13.

71 Larissa Stendie, 'Public Participation, Petro-Politics and Indigenous Peoples: The contentious Northern Gateway Pipeline and Joint Review Panel Process' (DPhil thesis, University of Oslo 2013).

${ }^{72}$ Elena Petkova and others, 'Closing the Gap: Information, Participation, and Justice in Decision-Making in the Environment' (World Resources Institute 2002) $<$ https://www.wri.org/sites/default/files/pdf/closing_gap_execsumm.pdf > accessed 1 August 2017. 
first, the right to access information; second, the right to participate in the decision-making process; and third, the right to access justice. ${ }^{73}$

The importance of the right of public participation is reflected through its inclusion in numerous international documents. The 1998 Aarhus Convention ${ }^{74}$ recognises that improved access to information and public participation in decision-making enhances the quality and implementation of decisions, contributes to public awareness of environmental issues, gives the public the opportunity to express its concerns and enables public authorities to take due account of such concerns. ${ }^{75}$ The aim of the Aarhus Convention is 'to further the accountability of and transparency in decision-making and to strengthen public support for decisions on the environment'. ${ }^{76}$ Unsurprisingly, the Aarhus Convention has its foundation in the Rio Declaration. ${ }^{77}$

Iran has endorsed the Rio Declaration and is also a party to the Aarhus Convention, which contains the broadest and most detailed articulation to date of the right to public participation. ${ }^{78}$ In order to give effect to the Aarhus Convention in Iran, this author would argue that it is necessary for Iran to adopt an accountability mechanism and legal frameworks that implements the respective provisions of the Aarhus Convention.

However, as it currently exists, the regulatory framework in Iran fails to adequately provide for this right of public participation. The following section therefore outlines this failure to capture each of the three pillars of the right.

\section{b) Access to Information}

Under the current regulatory scheme, there is no requirement to disseminate information to the public. ${ }^{79}$ The EIA takes place before project construction commences and the lack of transparency prior to commencement means that members of the public are deprived of their right to take legal action. ${ }^{80}$ An individual or group with knowledge of a project may object or seek injunctive relief against construction work but, generally, they are prevented from

\footnotetext{
${ }^{73}$ UNGA, 'Rio Declaration' (n 69).

${ }^{74}$ Convention on Access to Information, Public Participation in Decision-making and Access to Justice in Environmental Matters (adopted 25 June 1998, entered into force 30 October 2001) UN Doc/ACON (Aarhus Convention).

75 ibid, preamble.

76 ibid.

${ }^{77}$ Maria Lee and Carolyn Abbot, 'The Usual Suspects- Public Participation under the Aarhus Convention' (2003) 66 Modern Law Review 80, 87.

${ }^{78}$ UNGA, 'Report of the United Nations Conference on Environment and Development' (28 September 1992) UN Doc A/CONF.151/27.

${ }^{79}$ Sanaz Tajziehchi, 'Analysis of Environmental Impact Assessment in Iran for Transboundary Application' (International Conference on Environmental Challenges in the ROPME Sea Area, Kish Island, March 2013). 80 Charles Kersten, 'Rethinking Transboundary Environmental Impact Assessment' (2009) 34 Yale Journal of International Law 173, 203.
} 
accessing this information. This is because most relevant information will be classified as commercially sensitive. ${ }^{81}$ Further, project developers are not encouraged to publically release yearly reports on EIA findings, which also prevents citizens from obtaining information about potential environmental damage or damage that has already occurred. Provision is therefore not made for public disclosure of the assessments, as well as for public involvement in the authority's decision-making process. ${ }^{82}$ Robinson has argued, generally, that EIAs should play a role in raising public awareness, with EIA processes in other jurisdictions allowing for the disclosure of development plans to the public. ${ }^{83}$

Under the international standards, both EPs and IFC performance standards have not been adequately drafted to protect the rights of affected individuals. Despite including a variety of participatory rights, the release of the third iteration of EPs in 2012 (EP III) saw concerns raised over participation, disclosure and transparency under this EP framework. ${ }^{84}$ The definition of risk provided by the EPs has also been subject to scrutiny. As Abbott and Sindal state, what constitutes risk for a financial institution is markedly different from what constitutes risk for civil society groups and affected communities. ${ }^{85}$ As such, there is a structural limitation in the risk assessment protocols of the EPs, meaning that the utilised procedural models cannot adequately 'see' socio-environmental risk. ${ }^{86}$

In the commercial context, risk is generally conceived as the possibility of triggering unexpected, unlikely and detrimental consequences by means of decisions attributable to a decision maker. ${ }^{87}$ However, Luhmann proposes that risk assessment conducted through the lens of affected communities would better achieve the identification of potential and likely risks within a particular community. As Luhmann explains,

The outside world itself knows no risk, for it knows neither distinctions, nor expectations, nor evaluations, nor probabilities, unless self-produced by observer systems in the environment of other systems. ${ }^{88}$

c) Participation in the Decision-making Process

\footnotetext{
81 'Iran' $(E I A, 19$ June 2015) <www.eia.gov/beta/international/analysis.cfm?iso=IRN> accessed 8 June 2017.

82 ibid.

${ }^{83}$ Nicholas Robinson, 'International Trends in Environmental impact assessment' (2013) 9 Environmental Affair Law Review 591, 594.

${ }^{84}$ Joshua Lance, 'Equator Principles III: A Hard Look at Soft Law' (2013) 17 North Carolina Banking Institution $175,188-192$.

85 Keneth Abbott and Duncan Sindal, 'The Governance Triangle: Regulatory Standards Institutions and the Shadow of the State' in Walter Mattli and Ngaire Woods (eds) The Politics of Global Regulation (Princeton University Press 2009).

${ }^{86}$ Niklas Luhmann and Rhodes Barrett (trs), Risk: A Sociological Theory (Water de Gruyter 1993) 6.

87 ibid.

88 ibid 340.
} 
The ability to participate in the decision-making process is equally limited. The EIA framework has no provision to compel project sponsors to consult with local communities when developing environmental management plans for infrastructure projects. Similarly, it does not specify the right of affected communities to take part in negotiations.

Furthermore, the international standards do not adequately fill the gap left by the EIA framework. Principle 5 (Stakeholder Engagement) of the EPs requires that, for specified categories of projects, the borrower must consult with project-affected communities in a manner that is culturally appropriate. ${ }^{89}$ This principle of stakeholder engagement then goes on to require that, for projects 'with significant adverse impacts', this consultation must be include the 'free, prior, and informed consent' of affected indigenous communities. ${ }^{90}$ These specifications are designed such that projects must adequately incorporate the concerns of affected communities. ${ }^{91}$

However, affected communities have no right to veto a project. Furthermore, according to Haack, Schoenborn and Wickert, various actors have observed that the more rigorous EP requirements are circumvented by the EPFI, which classifies projects using the categories $\mathrm{A}$ (high risk), $\mathrm{B}$ (medium risk) and $\mathrm{C}$ (low risk) and thus determines what obligations fall to borrowers. ${ }^{92}$ This issue is compacted by the use of the word 'significant' in EP Principle 5, as its interpretation is at the discretion of the company, which causes 'the patchy application of standards' ${ }^{93}$ Barrett and Mack argue that how a project is categorised ultimately determines the degree to which it is subject to regulation. The categorisation process thus excludes community participation in a crucial element of a project's assessment. ${ }^{94}$

In the context of participatory decision-making, the Iranian model must ultimately be compared unfavourably to other jurisdictions, in which local communities have either been granted the right to veto or at least to review the final business development plan. ${ }^{95}$ In Canada, Belgium and Finland, affected communities are all encouraged to engage in negotiations, and

\footnotetext{
${ }^{89}$ Equator Principles (n 45) Principle 5.

90 ibid.

91 ibid.

${ }^{92}$ Patrick Haack, Dennis Schoenborn and Christopher Wickert, 'Exploring the Constitutive Conditions for a SelfEnergizing Effect of CSR Standards: The Case of the "Equator Principles" (2010) University of Zurich Institute of Organisation and Administrative Science IOU Working Paper No 115, 21 $<$ https://papers.ssrn.com/sol3/papers.cfm?abstract_id=1706267> accessed 15 September 2017.

${ }^{93}$ Editorial, 'Application of the Equator Principles lands adherents in hot water' The Banker (5 March 2007) < http://www.thebanker.com/Markets/Climate-Carbon/Application-of-Equator-Principles-lands-adherents-in-hotwater?ct=true $>$ accessed 7 July 2017.

${ }^{94}$ Patrick Haack, Dennis Schoeneborn, and Christopher Wickert, 'Talking the Talk, Moral Entrapment, Creeping Commitment? Exploring Narrative’ (2012) 33 Organization Studies 815, 844.

${ }^{95}$ Kashfi (n 19) 143.
} 
are provided access to information on the business project's purpose, nature and scale, its duration and any potential risks prior to its planning stage and commencement. ${ }^{96}$

\section{d) Access to Justice}

The third branch of the right to participation is meaningful access to justice. Yet, in Iran, a lack of transparency has prevented affected citizens from obtaining information that would smoothly facilitate access to justice. ${ }^{97}$ This principle of access to justice (interpreted in this context as a right to litigation) arises in a number of different ways. First, an individual may challenge a refusal to provide access to information. Second, an individual may seek damages related to harmful activities. Third, an individual may bring a legal case to seek the direct enforcement of an existing law. ${ }^{98}$

None of these options have been fully translated into the EIA. The Supreme Council of Environment has confirmed that the EIA does not establish liability on the part of either the government or corporations for acting in breach of EIA provisions, meaning no legal remedy or redress is afforded to marginalised communities. ${ }^{99}$ Based on the recent advisory opinion of the Supreme Council of Environment, liability only arises if the business development results in water and soil contamination. ${ }^{100}$

Iran's restrictive standing rules also impede access to environmental justice for affected communities. ${ }^{101}$ As such, actions brought by individuals are normally dismissed due to a lack of standing because the decision under challenge is not of direct or individual concern to the applicant or its member. ${ }^{102} \mathrm{~A}$ recent example of this is the development of oil refineries in the South Pars oil and gas field. ${ }^{103}$ A group of affected citizens filed a lawsuit for the damages they incurred as a result of destruction of ecosystem, but the civil court would not hear the case on the basis that there was no direct damage to the plaintiffs. ${ }^{104}$

\footnotetext{
${ }^{96}$ Nouri and Nikoomaram (n 31) 92.

97 David Hunter and Natalie Bridgeman, 'Narrowing the Accountability Gap: Toward a New Foreign Investor Accountability Mechanism’ (2008) 20 Georgetown International Environmental Law Review 187, 214.

98 ibid 399-400.

${ }^{99}$ Kashfi (n 19) 140-142.

${ }^{100}$ Decision No 144479/458 of the Supreme Environment Protection Council (12 October 2012).

101 Mohsen Morowati and Hassan Asilian, 'National Implementation Plan for the Stockholm Convention on Persistent Organic Pollutants' (Stockholm Convention Clearinghouse, July 2008) 22-23 $<$ http://chm.pops.int/Home/tabid/2121/Default.aspx> accessed 3 May 2017.

102 Hosein Valizadeh and Mohammad Reza Parvin, 'Middle East's Environmental Contamination and Responsibilities of Iran Regarding Compensation of Environmental Damages' (2014) 3 European Journal of Natural and Social Science 186, 190.

103 The South Pars field is the natural-gas condensate field located in the Persian Gulf. 'Iran's South Pars Gas Field' (The Iran Project, 19 August 2017) <http://theiranproject.com> accessed 3 June 2017.

${ }^{104}$ Peter Dauvergan, Historical Dictionary of Environmentalism (The Scarecrow Press 2009) 100, 101.
} 
Furthermore, even where the requisite standing is established, the criminal or civil courts do not have the right to suspend operations. ${ }^{105}$ The right to suspend an operation is vested in the Supreme Council of Environment, which uses broad discretion to determine whether a project imposes significant environmental harm if it proceeds. ${ }^{106}$ This institution is an affiliate of the petroleum ministry and is therefore more administrative than adjudicative. As such, its objective is to align with the overall desires of the government and, therefore, it could be said that it pushes the same oil and gas proliferation agenda as the government. ${ }^{107}$

Turning once again to international standards, the EPs offer very limited procedural protection to affected communities, in terms of accessing justice. Relying on international standards and industry best practice to promote environmental protection, as suggested in the Decree, is simply not effective. Based on Iranian civil procedure law, relying on international standards does not create an enforceable right because these standards are not applicable in Iranian courts. ${ }^{108}$ For example, plaintiffs cannot claim that failure to comply with the EPs is a cause of action in the Iranian courts. ${ }^{109}$

More broadly, whilst EP Principle 8 establishes a grievance mechanism, under this system NGOs can only hold borrowers, but not the EPFI (the lending bank), accountable. ${ }^{110}$ While financial institutions can monitor compliance through the agreed disclosure and reporting requirements, the EPs permit the bank to maintain an open line of credit, meaning that the contract and the associated procedures prescribed by the bank are upheld. ${ }^{111}$ Privity of contract between the lender and the borrower is also upheld, with little protection afforded to communities who remain unable to hold banks to account.

As discussed above, through loan agreements, a financial institution can prescribe and monitor a borrower's actions, yet no mechanisms exist under the EPs to require an EPFI to

\footnotetext{
105 ibid 101.

${ }^{106}$ Kashfi (n 19) 145.

107 'Supreme Council of Environmental Protection: New Appointments' (Centre for Sustainable Development and Environment, 28 November 2017) < http://www.cenesta.org/en/2017/11/28/supreme-council-ofenvironment-protection-new-appointments/> accessed 1 December 2017.

${ }^{108}$ Hajar Azari, 'The Effectiveness of International Law in The Iranian Legal System' (2014) 10 Islamic Studies and International Law 66, 68. The Civil Procedure Code of the Islamic Republic of Iran, Art 9, Chapter 1 Art 183. There is no provision stipulated for relying on international norms or principles in a domestic court.

${ }^{109}$ Flora Heidari, Farhad Dabiri and Mendi Heidari 'Legal System Governing on Water Pollution in Iran' (2017) 5 Journal of Geoscience and Environment Protection 36, 40.

${ }_{110}$ Nigel Clayton, 'Equator Principles and Social Rights: Incomplete Protection in a Self-Regulatory World' (2009) 11 Environmental Law Review 173, 180.

111 Andrian Lozinski, 'The Equator Principles: Evaluating the Exposure of Commercial Lenders to SocioEnvironmental Risk’ (2012) 13 German Law Journal 1490, 1495.
} 
sanction a borrower if the specified covenant is violated. ${ }^{112}$ In essence, the EPs do not prescribe any mitigating measures that should be taken by an EPFI if they encounter a violation of covenants that encompass EP policies. This lack of specificity means that EPFIs retain significant discretion in how to respond to any breach by the borrower. The Sakhalin II case serves as a good example demonstrating the level of commitment of the EPFIs to comply with EPs. EPFIs involved in the project faced public criticism due to their failure to ensure compliance with the EPs. ${ }^{113}$ Specifically, the content of the environmental assessment failed to include key environmental impacts and specific information regarding endangered species. It also lacked clarity regarding mitigation measures and the environmental protection of the relevant region. ${ }^{114}$ However, despite a clear violation of the EPs, the responsible EPFIs were not held to account for failing to ensure that the required assessment occurred. ${ }^{115}$

\section{PROPOSED STATUTORY FRAMEWORK}

This section proposes a new statutory framework for Iran, recommending accountability mechanisms that address the environmental and social concerns of indigenous communities. This proposed framework narrows the accountability gap that exists under the present EIA model and is designed to hold both government and international organisations accountable for environmentally harmful activities.

One of the major criticisms levelled against the Iranian framework is the lack of proper monitoring of oil and gas projects. ${ }^{116}$ The proposed model remedies this problem by replacing industry self-regulation with national legislation. This shift is predicated on the basis that monitoring and enforcement mechanisms are more effective if they are independent. ${ }^{117}$

The proposed framework suggests that accountability mechanisms should be enshrined in regulation adopted by the parliamentary and judicial branches, which have the power to engage in sufficient monitoring and follow through, as opposed to vesting highly discretionary powers in Iranian government bodies. The Ministry of Petroleum, which currently exercises a

\footnotetext{
112 Donald Schepers, 'the Equator Principles: a Promise in Progress?' (2011) 1 International Journal of Business and Society 90, 95.

${ }^{113}$ PLATFORM, 'Analysis of the Sakhalin II compliance with the Equator Principles' (World Bank Group, May 2004) < https://bankwatch.org/documents/analysis_equatorp_05_04.pdf > accessed 17 July 2017.

${ }^{114}$ Ray Chan, 'The Equator Principles: Loan Covenants' (2009) 12 Journal of International Banking and Finance Law 42.

115 Schepers (n 112) 99, 102.

116 Vivideconomics, 'Monitoring and Evaluation Frameworks and Performance and Governance of International Funds Report' (African Development Bank 2011) <https://www.afdb.org/> accessed 5 June 2017.

117 Sarah Seck, 'Indigenous Rights, Environmental Rights, or Stakeholder Engagement' (2016) 12 McGill International Journal of Sustainable Development Law \& Policy 53, 66-75.
} 
high degree of discretion in managing oil and gas ventures, closely adheres to the agenda of the government. According to the Sixth Development Plan, the main objective of the Ministry of Petroleum, along with the NIOC, is to emphasise the development of gas and oil production capacity. ${ }^{118}$ This type of fiscal regime is designed to prioritise economic growth and development over environmental concerns. ${ }^{119}$

\section{Proposed Model - a Right to Public Participation}

As explained in the first section, the current EIA framework demonstrates a lack of government commitment to environmental issues. ${ }^{120}$ As such, this article proposes that Iranian law must be reformed to proactively regulate the oil and gas industry and prevent environmental damage. The proposed model introduces preventative measures, recommending the adoption of statutory provisions that allow for the anticipation and prevention of potential environmental damage. Furthermore, given the predominantly soft nature of norms such as the EIA and EPs, it is proposed that public participation as a right ought be strengthened to address community and environmental concerns.

The proposed solution would therefore enshrine public participation in a statutory framework, providing the necessary language to enforce compliance. Enhanced public participation would provide a means of managing social conflict and minimising the frequency and magnitude of conflicts that arise over the course of a project. ${ }^{121}$ Due to the proactive nature of the right to participation, one aspect of the right is an obligation to inform local communities about possible socio-environmental risks prior to the commencement of the project. This can be viewed as preventative action taken to avoid future harm. Further, enhancing the right to public participation would lead to greater accountability and effectiveness in governmental decision-making. It would also provide indigenous communities with the leverage to ensure that commitments to environmental standards are met on the part of government and organisations such as big oil companies.

This section will therefore outline a proposed regulatory model for Iran which addresses the three branches of the right to participation: the right to access information, the right to participate in the decision-making process, and the right to access justice.

\footnotetext{
$118 \quad$ Iran's $\quad 6^{\text {th }} \quad$ Five- $\quad$ Year $\quad$ Development $\quad$ Plan $<$ http://en.nioc.ir/Portal/File/ShowFile.aspx?ID=df14f086-5eee-4b8> accessed 7 July 2017.

119 Hebert Smith Freehills 'The New Iranian Petroleum Contract - Government Approval' (Legal Briefing, 9 August 2016).

${ }^{120}$ Kahsfi (n 19).

${ }^{121}$ Bende Toth, 'Public Participation and Democracy in Practice- Arhus Convention as Democratic Institution' (2010) 30 Journal of Land Resources \& Environmental Law 295, 323.
} 


\section{e) Right to Access Information}

As established in the previous section, under the current Iranian EIA model, there is no requirement to disseminate information to the public regarding environmental concerns related to projects in the oil and gas industry. Nor does the EIA framework compel project sponsors to publicly release annual reports on their EIA implementation processes. Easy access to information must therefore be incorporated into legislation and reports must be provided in local languages specific to where the project is taking place. There should also be consistency in reporting in order to avoid compromising the efficacy of the reporting process. ${ }^{122}$

The inclusion of a right to access information is imperative to any future regulatory model in Iran, as it places both a reactive and proactive duty upon the government to provide certain information to the public, ${ }^{123}$ without being asked for the information in the first place. ${ }^{124}$ This model would also require actors in oil and gas exploration ventures, such as project sponsors and lenders, to take an active role in disseminating information to the public, by imposing periodic reporting requirements on companies.

The right to access information can be brought about in various ways. Firstly, this right can be implemented by informing the public about a proposed activity that may impact on their environment. ${ }^{125}$ Early access to information is essential to preventing imminent harm. ${ }^{126}$ As Rose notes, if the information regarding harm is disseminated before project construction commences, it will give opponents time to seek injunctive relief and enjoin wrongful conduct, prior to any action commencing, thus preventing any damage from taking place. ${ }^{127}$ Furthermore, public knowledge of pollution as a result of industry production can lead to industry self-regulation. ${ }^{128}$

This disclosure requirement should not be limited to the pre-construction phase. These new statutory provisions should also impose obligations on both lenders and project sponsors to disclose project-specific information throughout its operation. Ongoing public disclosure requirements would help identify potential, unknown, or amplified risks that may arise after a

\footnotetext{
122 Kathryn Tomlinson, 'Indigenous rights and Extractive Resource Projects: Negotiations over the Policy and Implementation of EPIC' (2017) The International Journal of Human Rights 1, 2.

${ }^{123}$ Hunter and Bridgeman (n 97) 211, 215.

${ }^{124}$ Sarah Seck, 'Home State Responsibility and Local Communities: The Case of Global Mining' (2008) 11 Yale Human Rights \& Development Law Journal 177, 198.

125 Jonas Ebberson, 'Public Participation in Environmental Matters', Max Planck Encyclopaedia of Public International Law(2009) <http://opil.ouplaw.com/view/10.1093/law:epil/9780199231690/law9780199231690-e1769> accessed 20 January 2018.

${ }^{126}$ Ian Rose, 'Industry and Access to Information on the Environment' [1998] 8 Environmental Law Journal 251, 263.

127 ibid 254.

128 ibid 260.
} 
project has commenced. ${ }^{129}$ In turn, this would help the community to take proactive measures, such as seeking injunctions against the project.

In order for the right to access information, and thus the right to public participation, to be effective, it is critical that vital information is disseminated in a manner that enables the public to understand and respond. This means information disclosed should be clear, detailed and in a form that can be comprehended. For example, the scope of the right to information should include the disclosure of detailed information about the project, its likely effect on the environment and livelihoods and, further, alternatives to the proposed project. ${ }^{130}$ This would simplify the discovery process and eliminate difficulties in cases where a citizen may need to establish that a particular actor is causing harm. ${ }^{131}$ This is important because, generally, the company causing environmental harm possesses the relevant evidence and it can be challenging to trace causation to that company without access to information. In addition, the affected community or aggrieved party often lacks the scientific and legal capacity to present convincing evidence of environmental violation. ${ }^{132}$

It is acknowledged that certain information may be commercially sensitive and should remain confidential, however, placing an obligation on companies to disclose relevant information should not prompt reluctance from financial institutions to invest in projects. Instead the proposed model aims to strike a balance between the disclosure of necessary information and the issue of confidentiality. To accomplish this, and contrary to the international standards which allow financial institutions to determine which information can be considered 'necessary', ${ }^{133}$ the author proposes a mechanism whereby independent advisers are appointed by local courts specialising in environmental issues to determine the scope of disclosure required. It ought to be necessary to disclose information regarding a company's compliance with environmental regulations, in order to provide a complete assessment of the risks imposed on local communities. This means affected communities being given access to

\footnotetext{
129 Benjamin Richardson, 'Protecting Indigenous Peoples through Socially Responsible Investment' (2007) 6 Indigenous Law Journal 205, 234.

${ }^{130}$ Chilenye Nwapi, 'A legislative Proposal for Public Participation In Oil and Gas Decisions-making in Nigeria' (2010) 54 Journal of African Law 184, 191.

${ }^{131}$ Donald Zillman, Alastair Lucas and George Pring (eds), Human Right In Natural Resource Development: Public Participation in the Sustainable Development of Mining and Energy Resources (Oxford University Press 2011).

132 ibid.

133 Lozinski (n 111) 1496, 1501.
} 
information regarding the purpose, nature and scale of projects, the duration of project activities and any potential risks involved. ${ }^{134}$

\section{f) Right to Participate in Decision-making}

As stated in the previous section, the right to participate in decision-making processes is not given effect under Iran's regulatory scheme. However, inclusion in decision-making is critical to ensure trust, cooperation and respect for the cultural integrity of indigenous people and their communities. ${ }^{135}$ As such, the proposed model would enshrine the right of communities and individuals to participate in decision-making processes. It is anticipated this right would extend to permitting participation in decisions made prior to executive action being taken.

Inevitably, this right is linked with the right to access information considered above. Those who wish to participate in decision-making processes must be appropriately informed prior to doing so. ${ }^{136}$ Individuals thus need access to information within a reasonable timeframe and reasonable notice must be given to those individuals who wish to take part in the decisionmaking process. ${ }^{137}$ The right to participate in decision-making should also include ensuring indigenous people and communities are given a reasonable amount of time to comment on proposed projects, in order to allow them to gather pertinent information and prepare comments. ${ }^{138}$

Effective participation also requires the strengthening of local institutions. ${ }^{139}$ Local institutions in Iran, such as local committees, municipalities and ethnic societies need to be given the practical capacity to participate in these processes. This means local institutions must be funded sufficiently, given appropriate venues and empowered to achieve meaningful public participation. This author would suggest, in order to support full and effective public participation, the creation of a participant-funding scheme that addresses the financial imbalance amongst the various stakeholders in gas and oil projects. For example, the Ahwazi are often the poorest members of Iranian society, ${ }^{140}$ and without financial assistance or incentive, many will be unable to make use of participation opportunities offered to them.

${ }^{134}$ Ellen Hey, 'Public Values and Public Participation in Decision-Making in Times of Privatization (comments)' (2012) 4 Erasmus Law Review 39, 44.

135 James Maurici and Richard Moules, 'The influence of the Aarhus Convention on EU Environmental Law: Part 1' (2013) 12 Journal of Planning and Environmental Law 1496.

${ }^{136}$ Leslie-Anne Duvic-Paolic, 'The Status of the Right to Public Participation in International Environmental Law: An Analysis of the Jurisprudence’ (2013) 23 Yearbook of International Environmental Law 80.

137 ibid.

${ }^{138}$ Hunter (n 43) 424.

139 Convention Concerning Indigenous and Tribal peoples in Independent Countries (adopted 27 July 1989, entered into force 5 September 1991) ILO C169.

140 UNPO, ‘Ahwazi: Country's highest Poverty Rate for Arab Ahwazi' (UNPO, 6 February 2013) $<$ http://unpo.org/article/15469> accessed 9 January 2017. 
It is proposed that the inclusion of a right to participate in the project decision-making processes should include a right for marginalised communities to veto or approve the final stages of projects, ${ }^{141}$ thereby increasing the legitimacy of the entire venture.

However, the feasibility of widening the participatory rights of affected communities this far ought to be explored further. Non-executive participation in the decision-making process could be perceived as a hindrance, affecting a project's commercial and economic viability and jeopardising deals. Nancy Spyke contends that the public is often too emotional and ill-equipped to deal with technical matters and participation programmes surrounding environmental decisions require the compilation of copious amounts of data that can overwhelm administrative resources. ${ }^{142}$ This argument holds some merit, however, on balance this criticism is offset by the benefits of a statutory right to participation. Further, the proposed mechanism would ensure local communities are informed of the potential negative effects of a project but also its positive attributes.

For example, an emphasis on participatory rights would allow oil and gas companies to demonstrate how a project would respond to the needs of local communities in the Ahwaz region. This could be through, for example, the creation of employment that, in turn, improves the economy of the impoverished area, providing business opportunities, and contributing to aging infrastructure of Ahwaz, which is causing transportation issues. ${ }^{143}$ In addition, enshrining the right to participate in this regulatory model would address legitimacy concerns some communities have raised. ${ }^{144}$ The Ahwazi population have long felt alienated by the Iranian central government, which has failed to properly address some of their needs. ${ }^{145}$ The Ahwazi believe they have been left out of critical decision-making processes, with their voices and concerns not taken into consideration. This, according to the Ahwazi, has had a direct effect on their livelihood and their environment. This proposed model would allow communities to take an active role during important negotiation processes.

\footnotetext{
141 Nahuel Maisley, 'The Case for Large Participatory Conferences as a Means of Decision Making in International Environmental Law' (2013) 25 Environmental Claims Law Journal 11, 14.

${ }^{142}$ Nancy Spyke, 'Public Participation in Environmental Decision-Making at the New Millennium: Structuring New Spheres of Public Influence’ (1999) 26 Boston College Environmental Affairs Law Review 263, 292.

143 Rahim Hamid, 'Report Exposes widespread job discrimination exercised against Ahwazi Arab people' (Minority voices Newsroom 16 June 2016) < http://www.minorityvoices.org/news.php/en/1785/iran-reportexposes-widespread-job-discrimination-exercised-against-ahwazi-arab-people> accessed 3 May 2017.

${ }^{144}$ Daniel Esty, 'The World Trade Organization's Legitimacy Crisis' (2002) 1 World Trade Review 22, 32.

145 'Iran's Complex Khuzestan Region Through the Eyes of its people' The Guardian (London, 24 June 2014) $<$ https://www.theguardian.com/world/iran-blog/2014/jun/24/iran-arab-khuzestan-education-politicsminorities> accessed 2 May 2017.
} 
It is also important to consider whether it is realistic to expect financial institutions to comply with this type of accountability mechanism, particularly as it would empower minority groups to veto a project and thereby potentially threaten foreign investment. This is particularly important in Iran, a country desperate for investment funds and with competition for capital. ${ }^{146}$

Ultimately, corporations aim to yield sufficient profits. This author contends, however, that companies need to re-think profit making ventures and focus on long-term, as opposed to short-term, profits that are more aligned with an environmentally sustainable agenda. It cannot be ignored that project-financed facilities must generate sufficient cash flows from operations to provide an adequate return on investment. If those cash flows are insufficient for meeting the project's obligations, then financiers or creditors have limited recourse to recoup any losses suffered as a consequence of non-performance. As Hoffman states, lenders are repaid only from the cash flow a project has generated, so it is critical for banks that a project be successful in the long run. ${ }^{147}$ Yet, as Amalric explains:

environmental risks may have a direct bearing on project returns, when, for instance, the life expectancy of a dam is shortened by unexpected ecological processes; and social risks, in the form of local resistance against unpopular projects can delay construction and normal operations. ${ }^{148}$

As such, financing a project that is environmentally damaging inevitably has significant implications for both a project and its financers. It is therefore in the self-interest of financial institutions, such as commercial banks and insurance investment agencies, to consider environmental risks throughout the project finance phase. Improving the participatory rights of local communities, and increasing engagement in more environmentally sustainable projects, could assist corporations to avoid potentially costly problems, such as project opposition, development-site protests, reputational damage to the oil company, loss of financing and insurance, and potential litigation costs. ${ }^{149}$

Properly enshrining the right to participate in decision-making may also decrease the criticism faced by companies from civil society. Investment in reckless projects can distort a financer's image and undermine their reputation; the Three Gorges Dam project offers an

\footnotetext{
${ }^{146}$ Najmeh Bozorgmehr, Michael Stothard and Andrew Ward 'Iran aims for more foreign oil and gas investment after total deal' Financial Times (Tehran, 6 November 2016) <https://www.ft.com/content/9db5e152-a5a911e6-8b69-02899e8bd9d1> accessed 1 December 2017.

${ }^{147}$ Hoffman (n 57).

148 Amalric (n 32) 12.

${ }^{149}$ David Spence, 'Corporate Social Responsibility in the Oil and Gas Industry: the Importance of Reputational Risk’ (2010) 86 Chicago Kent Law Review 59, 66.
} 
example of this. ${ }^{150}$ In fact, reputational risk is commonly considered an indirect risk for a lender in project-financing initiatives. Reputational risk generally means that the true financial loss is almost impossible to calculate. ${ }^{151}$ The importance of mitigating reputational risk exposure is currently reflected in international standards, which were developed, in part, due to the reputational risk faced by financial institutions engaged in project financing. As Conley and Williams claim, 'NGO[s] pressure shamed them into it'. ${ }^{152}$ Moreover, NGOs not only serve as a mouthpiece for the public will but also promote environmental compliance.

Further, enshrining a right to public participation would allow local communities to play a critical role in environmental management, by sharing their knowledge of the local environment or any conservation issues pertinent to the project at hand. In the long run, this would facilitate the adaptability of projects to local environments. ${ }^{153}$

\section{g) Right to Access Justice}

To complement the preventative measures discussed above, the proposed regulatory framework would also create a grievance mechanism that would ensure indigenous communities have an effective way to access justice. For the grievance mechanism to be effective, it must be transparent and credible. ${ }^{154}$ This grievance mechanism should ensure that a company receives, evaluates and addresses project-related grievances. ${ }^{155}$ This section does not propose a specific grievance mechanism but explores options that could work in the Iranian context.

One possible grievance mechanism is the development of informal procedures enacted at the local level. For example, special project review committees could make a review process available where a party believes that a project is not being conducted in accordance with prescribed rules. Aggrieved parties would be able to access informal appeal procedures, allowing companies and local communities an avenue to resolve their disputes without resorting to costly litigation. ${ }^{156}$ An added advantage of an informal mechanism is that it offers

\footnotetext{
${ }^{150}$ McCutheon (n 16) 399.

151 ibid 390-392.

152 John Conley and Cynthia Williams, 'Global Banks as Global Sustainability Regulators? The Equator Principles’ (2011) 33 Law \& Policy 542, 558.

153 Alastair Lucas and Heather Lilles, 'Opportunities for Public Participation in the Regulation of Hydraulic Fracturing Operations in Alberta' (2016) 54 Alberta Law Review 185.

${ }^{154}$ IFC, 'Addressing Grievance from Project-affected Communities: guidance for projects and companies on designing grievance mechanisms' (Good Practice Note, International Finance Corporation 2009) 7 $<\mathrm{http}$ ://www.ifc.org/> accessed 05 June 2017.

155 ibid 29, 27.

156 ibid 22.
} 
a locally-based, simplified and mutually beneficial way to settle disputes. ${ }^{157}$ The author argues that this form of dispute resolution would assist in strengthening company-community relationships, while recognising the right of complainants to a dispute mechanism.

Any grievance mechanism adopted should also place an obligation on companies to develop tailored approaches for raising and resolving grievances that are acceptable to the local indigenous people. A project-level grievance mechanism would be useful in taking into account specific cultural issues, as well as incorporating traditional mechanisms for raising and resolving issues. ${ }^{158}$ To accomplish this, companies could appoint an expert to determine the level of detail required for the grievance mechanism to operate. The expert would then take into account cultural attributes, customs and tradition, including differences in the roles and responsibilities of subgroups in setting up a grievance mechanism. The ways in which the communities in question have traditionally expressed and dealt with grievances would also be taken into account. ${ }^{159}$ This may require the development of procedures, policies and guidelines for staff to follow.

The proposed mechanism should also establish liability for corporations in breach of relevant statutory provisions. If project-sponsors or financial institutions are in violation of any of the stipulated obligations, then the Public Ministry should be responsible for enforcing corrective actions for non-compliance. In this context, enforcement refers to the means by which a regulator may seek to address non-compliance with a regulatory framework. As Ayres and Braithwaite note, this could include both applying sanctions and adopting less coercive means with companies in breach of regulations, such as persuasion, and providing information on applicable standards. ${ }^{160}$

Arguably, excessive reliance on coercive means of enforcement adds to the risk of alienating regulated entities, causing them to evade regulation or hide material information from a regulator or public ministry. ${ }^{161}$ It is therefore recommended that regulators adopt noncoercive enforcement mechanisms as a first resort. The use of non-coercive enforcement mechanisms could give local people the opportunity to ascertain an institution's compliance

\footnotetext{
${ }^{157}$ CAO, 'A Guide to Designing and Implementing Grievance Mechanism for Affected Communities" (Advisory Note, Office of the Compliance Officer/Ombudsman 2012) $<$ www.caoombudsman.org/housework/advisor/documents/implemgrieveng.pdf $>$ accessed 5 June 2017.

158 ibid 8, 13-14.

159 ibid 17, 40-41.

${ }^{160}$ Ayres and Braithwaite (n 49) 283.

${ }^{161}$ Carlo de Stefano, 'Reforming the Governance of International Financial Law of the Era of Post-Globalization' (2017) 20 Journal of International Economic Law 509, 522.
} 
with environmental and social policies. ${ }^{162}$ There are various non-coercive methods available. For example, a regulator could persuade an entity to comply with regulations by appealing, as Sarro has noted, to their 'sense of social responsibility'. ${ }^{163}$ Alternatively, allowing affected people to voice their grievances regarding non-compliance directly to the project developer or financial institution would be beneficial, as an open line of communication allows the smooth operation of the project. ${ }^{164}$ This would pre-empt costly litigation. ${ }^{165}$

Ultimately, however, enforcement mechanisms are only effective where there is a genuine belief that failure to comply with regulators' less coercive means of enforcement will lead to the imposition of severe enforcement actions. ${ }^{166}$ Under the proposed model, third parties and public prosecutors should be empowered to launch a civil complaint, criminal proceedings or seek different remedies in court against those actors who failed to comply with the terms stipulated in the proposed framework. As stated previously, Iran's restrictive standing rules impede access to environmental justice for the non-privileged. Consequently, the framework proposed here would also confer broad standing on public prosecutors to initiate legal proceedings as well as to third parties and private citizens. ${ }^{167}$ This proposed mechanism would have a low threshold for parties to establish that injunctive relief is necessary.

It must be noted that the proposed enforcement mechanism embodies both criminal liability and civil liability. One of the purposes of establishing criminal liability is to create a deterrent against acts that amount to violation of the provisions mentioned above. ${ }^{168}$ Such violations will cause serious harm and should therefore give rise to criminal responsibility. This is because non-compliance amounts to breach of an obligation that is essential for the preservation of the land of local communities and their rights to enjoy a safe and healthy environment. 169

\footnotetext{
${ }^{162}$ Ayres and Braithwaite (n 49) 24, 26.

163 Sarro (n 63) 1552.

${ }^{164}$ Patrick Keenan, 'Evidenced-Based Stakeholder Engagement: The Promise of Randomized Control Trials for Business and Human rights' (2015) 3 Indiana Journal of Law \& Social Equal 55.

165 Tais Ludwig, 'Recommendations for Addressing Environmental Impacts of African Development Projects Funded by Chinese Banks' (2015) 15 Sustainable Development Law \& Policy 11, 13.

${ }^{166}$ Baldwin and Black (n 50) 64, 66.

${ }^{167}$ M Faure and M Visser, 'How to Punish Environmental Pollution- Some Reflections on Various Models of Criminalization of Environmental Harm' (1995) 3 European Journal of Crime, Criminal Law and Criminal Justice 316.

${ }^{168}$ Michael Bothe, 'Criminal Responsibility For Environmental Damage in Times of Armed Conflict' (1996) 69 International Law Studies Series 473, 475.

${ }^{169}$ UNCHE 'Stockholm Declaration of the United Nations Conference on the Human Environment' (16 June 1972) UN Doc A/CONF. 48/14/REV.1.
} 
A credible grievance mechanism must also be accessible to all segments of the affected communities. ${ }^{170}$ As such, this mechanism should be free of cost for the aggrieved party. Claims for non-compliance in oil and gas operations can be complex and costly. Often, the aggrieved party has to hire an attorney with the resources to investigate the circumstances of noncompliance and to isolate the causes in order to build a strong case on behalf of the aggrieved party. ${ }^{171}$ Historically, local indigenous communities have been further impeded by the absence of effective legal aid for litigation against powerful oil companies. One potential way to address the financial burden a free grievance mechanism would place on the judiciary would be for a share of the profits from all projects that are found to be non-compliant to be directed into a fund. This fund would be used to pay for the legal costs and/or compensation for parties seeking to utilise the grievance mechanism. ${ }^{172}$ Ultimately, extending legal aid to civil and criminal claims arising from the violation of the above-mentioned provisions would help the aggrieved parties overcome the challenges of pursuing the oil companies. ${ }^{173}$

Finally, the judiciary should embrace the right of participation in the context of environmental law and the right of indigenous people. To do this, the judiciary must be competent to hear cases where there has been a breach of the right to information and to participate in decision-making processes. ${ }^{174}$ This should include an ability to award compensation to the aggrieved party and declaratory relief to prevent subsequent harm. ${ }^{175}$ To ensure as uniform interpretation of statute as possible, judges who interpret the provisions should be trained as experts in complying with and implementing the provisions, possess expert knowledge in environmental law and be trained to respect the rights of indigenous people. ${ }^{176}$

\section{CONCLUSION}

This paper has attempted to illustrate that Iran's lack of environmental regulation, against the backdrop of its burgeoning oil and gas industry, poses a threat to the rights of its indigenous

\footnotetext{
${ }^{170}$ Kishanthi Parella, 'The Stewardship of Trust in the Global Value Chain' (2016) 56 Virginia Journal of International Law 585, 612-641.

$171 \mathrm{~J}$ Berton Fisher and William Keffer, 'Selection, Use and Management of Experts in Environmental Legal Practice' (1998) 33 Tulsa Law Journal 1003, 1005-1006.

172 Engobo Emeseh, 'Mainstreaming Enforcement for the Victims of Environmental Pollution: Towards Effective Allocation of Legislative Competence under a Federal Constitution' (2012) 14(3) Environmental Law Review 185, 189.

173 ibid 188-189.

${ }^{174}$ Dinah Shelton, 'Human Rights, Health and Environmental Protection: Linkages in Law and Practice' (2007)

11 Human Rights \& International Legal Discourse 9, 18.

175 ibid 14, 19.

${ }^{176}$ Craig Ford 'Site-level grievance and community response mechanisms' (The Mining Association of Canada, November 2015) 15 <http://mining.ca/sites/default/files/documents/Site-Level-Grievance-Guide-English.pdf> accessed 5 June 2017, 15.
} 
people and their environment. The current EIA mechanism is insufficient to protect the rights of affected communities. Further, it fails to establish any liability on the part of environmentally destructive companies. Properly enshrining the right to public participation in Iranian regulations, through allowing parties to access information and participate in decision-making processes, as well as establishing grievance mechanisms, could have the effect of striking a balance between the running of oil and gas projects and protecting the environment.

Ultimately, it is essential that Iran devise a national regulatory system to protect the rights of indigenous people. This paper has accordingly proposed a framework that could anticipate, address and prevent the potential harm that indigenous people and their environment face. The right of public participation is enshrined in this proposed framework and could empower affected communities by granting them recourse to legal action. Simultaneously, this new framework could create a more robust system of accountability for corporations. It would accelerate access to information, enable communities to participate in decision-making processes before project construction commences and, crucially, it could provide indigenous communities with a platform to voice their concerns. In order to guarantee effective participation, such special consideration should be given to the culture, tradition and customs of local communities. 